\title{
Supplementation with fish oil reduces morphological aspects of muscle damage induced by intense exercise in rats
}

\author{
Suplementação com óleo de peixe reduz aspectos morfológicos de lesão muscular \\ induzida por exercícios intensos em ratos
}

\author{
Daniel Pereira Coqueiro $\mathbb{D}^{1,2} \llbracket$, Patrícia Cincotto dos Santos Bueno $\mathbb{D}^{3}$, Manuel de Jesus Simões $\mathbb{D}^{1}$ \\ Departamento de Biologia Estrutural e Funcional da Universidade Federal de São Paulo (UNIFESP). São Paulo, SP, Brasil. \\ 2 Faculdade de Ensino Superior do Interior Paulista (FAIP) Marília, SP, Brasil. \\ ${ }^{3}$ Faculdade de Medicina da Universidade de Marília (UNIMAR). Marília, SP, Brasil.
}

How to cite this article:

Coqueiro DP, Bueno PCS, Simões MJ. Supplementation with fish oil reduces morphological aspects of muscle damage induced by intense exercise in rats. Sci Med. 2018;28(4):ID31470. DOI: 10.15448/1980-6108.2018.4.31470

\section{ABSTRACT}

AIMS: To investigate the effects of resistance exercise and fish oil intake on muscle morphology in Wistar rats.

METHODS: Forty-eight animals that performed resistance exercise were initially divided into two groups. One group did not take fish oil and the other group took fish oil. The animals of the second group underwent training and took fish oil for eight weeks. At the end of the last resistance exercise session, the 48 rats were organized into six subgroups of eight each, according to the time gap (12, 24 or 48 hours) elapsed until the gastrocnemius muscle withdrawal procedure. At each established time after the last resistance exercise session, the gastrocnemius muscle was removed for morphological analysis.

RESULTS: Skeletal muscle cells of the animals that did not receive fish oil presented higher scores of edema, especially those from the groups that had their muscles withdrawn at 24 and 48 hours of time gap. As for the group that took fish oil, we observed a smaller amount of inflammatory infiltrate and reduced areas of necrosis compared to animals that exercised without the use of fish oil, at all post-exercise time gaps. CONCLUSIONS: Fish oil intake attenuated morphological changes in muscle tissue after high-intensity exercises.

KEYWORDS: inflammation; exercise; muscle tissue; polyunsaturated fatty acids; nutrition.

\section{RESUMO}

OBJETIVOS: Investigar os efeitos do exercício resistido e da ingestão de óleo de peixe na morfologia da fibra muscular em ratos Wistar. MÉTODOS: Quarenta e oito animais realizaram exercício resistido e foram divididos inicialmente em dois grupos. Um dos grupos não recebia óleo de peixe e o outro grupo ingeria o óleo de peixe. Os animais do segundo grupo realizaram o treinamento e ingeriram o óleo de peixe por um período de oito semanas. Ao final da última sessão de exercício resistido os animais foram organizados em seis subgrupos de oito cada, segundo o intervalo de tempo (12, 24 e 48 horas) transcorrido até o procedimento de retirada do músculo gastrocnêmio. Em cada tempo determinado após a última sessão de exercício resistido, o músculo gastrocnêmio foi retirado para análise morfológica.

RESULTADOS: As células do músculo esquelético dos animais que não receberam óleo de peixe apresentaram escores maiores de edema, especialmente as dos grupos que tiveram os músculos retirados em 24 e 48 horas. No grupo que ingeriu o óleo de peixe observou-se menor quantidade de infiltrado inflamatório e áreas de necrose reduzidas em comparação com os animais que se exercitavam sem o uso de óleo de peixe, em todos os intervalos de tempo pós-exercício.

CONCLUSÕES: A ingestão de óleo de peixe atenuou as alterações morfológicas no tecido muscular após exercícios de alta intensidade. DESCRITORES: inflamação; exercício; tecido muscular; ácidos graxos poli-insaturados; nutrição. 
Abbreviations: DHA, docosahexaenoic acid; EPA, eicosapentaenoic acid; EX, group of rats that did resistant exercises and did not receive fish oil; EXFO, group of rats that did resistant exercises and received fish oil; IL, interleukin; PUFA, polyunsaturated fatty acids; TNF- $\alpha$, tumor necrosis factor-alpha.

\section{INTRODUCTION}

Nutritional supplements for reaching recommended daily needs have been widely used in different sports modalities. Natural components of numerous foods have physiological effects and some of them are considered useful to improve sports performance or to prevent injury $[1,2]$.

Some studies suggest that the use of creatine may reduce muscle damage or improve recovery after intense exercise. Plasma levels of the enzymes creatine kinase and lactate dehydrogenase, and inflammatory indicators such as prostaglandins, tumor necrosis factor alpha (TNF- $\alpha$ ) and C-reactive protein were decreased with the use of this supplement [3-6]. Branched chain amino acid supplementation was considered a potential nutritional strategy to avoid or at least alleviate exerciseinduced muscle damage or its consequences $[7,8]$.

Among other food components that have physiological action and are considered a functional substance, the compounds rich in polyunsaturated fatty acids (PUFA) of type omega-3 have aroused the researchers' interest and also caught considerable attention concerning nutritional support to maintain muscle fiber integrity and damage inhibition after exercise $[2,9-11]$. This attention is related to the antiinflammatory and immunomodulatory properties conferred to these fatty acids $[12,13]$.

Omega-3 PUFA have to be obtained in adequate quantities for human nutrition, since mammals do not synthesize this type of fat. They are found in high concentrations, in the form of eicosapentaenoic acid (EPA) and docosahexaenoic acid (DHA), in several foods, particularly in some cold and deep water fish, such as mackerel, salmon, and tuna [2,9, 14-16]. Among the beneficial effects of fish oil, its action on decreasing the synthesis of potent chemical mediators of inflammation derived from arachidonic acid, such as prostaglandin, thromboxane, prostacycline and leukotriene, ensuring anti-inflammatory effect, is highlighted $[12,13,17]$.

The consumption of compounds rich in omega-3 PUFA may be associated with decrease of muscle damage indirect markers [9-11, 18-20]. Knowledge about these benefits is important for athletes, who are constantly subjected to muscular damage, especially when they perform high-intensity eccentric exercises. For Haidamus [21], the use of foods rich in omega-3 PUFA, EPA and DHA by athletes may minimize the effects of the inflammatory process on the injured muscle by decreasing the synthesis of potent chemical mediators of inflammation and, therefore, reducing their recovery time and improving their responses to high-intensity exercises [22]. However, data are still conflicting as to whether omega-3 PUFA suppress the inflammatory response after high-intensity exercise. Thus, this study aimed to test the hypothesis of possible anti-inflammatory effect and contribution to muscle damage prevention of omega-3 PUFA (EPA and DHA) derived from fish oil after high-intensity exercises. This article also aims to investigate changes in the skeletal muscle in rats submitted to exercise with weights and fish oil intake.

\section{METHODS}

\section{Experimental animals}

A total of 48 male Wistar rats (Rattus norvegicus) with a mean age of 120 days, weighing between $220 \mathrm{~g}$ and 270g, provided by the Animal Model Experimentation Center (CEMA) at the University of Marília/UNIMAR were used. The animals were transferred to the experimental area and kept in climatized environment with temperature control (between $22^{\circ} \mathrm{C}$ to $24^{\circ} \mathrm{C}$ ), and light and dark cycle of 12/12 hours. The animals were kept in polyethylene cages (four animals per cage) for eight days and received Nuvilab ${ }^{\circledR}$ commercial pelleted food (by Nuvital) and water ad libitum.

This study was approved by the Research Ethics Committee of the Federal University of São Paulo (UNIFESP), with protocol number 0354/12. During the experiment, the animals were treated according to the UNIFESP document "Guide for the Care and Use of Experimental Animals". The study complied with the Brazilian guidelines for the care and use of animals for scientific and didactic purposes.

\section{Experimental groups}

All the animals were kept in collective cages and performed resistance exercise three times a week for eight weeks. They were initially divided into two groups of 24 animals each: the resistance exercise group (EX) received no fish oil; and the resistance exercise and fish oil group (EXFO) received fish oil after each resistance exercise session. At the end of the last resistance exercise session, the animals of the two groups were divided into subgroups with eight 
animals each, according to time (12, 24 and 48 hours) for the gastrocnemius muscle withdrawal procedure. At the established time after the last resistance exercise session, the gastrocnemius muscle was removed for morphological analysis.

\section{Resistance exercise protocol}

Exercise consisted of vertical jumps to the surface in a pool $50 \mathrm{~cm}$ height by $25 \mathrm{~cm}$ diameter, filled with $35 \mathrm{~cm}$ of heated water $\left(30^{\circ} \mathrm{C}\right)$. To perform the exercises, an additional load was attached to the animal thorax [23]. The exercise protocol consisted of 10 repetitions for four sets with a $60 \mathrm{~s}$ rest among sets, three times a week for eight weeks.

The load adjustments were made weekly, considering the body weight, which was controlled at the same frequency. To reduce stress, the animals were adapted to the aquatic environment for one week before the beginning of the protocol. This adaptation consisted of resistance exercise sessions with load (30\% of body weight) attached to the thorax, for five consecutive days. After the adaptation week, the experimental resistance training protocol was started, as described by Renno et al. [24] and Secchi et al. [25]:

- First and second weeks: 4 series of 10 jumps, with overload of $50 \%$ of the body weight;

- Third and fourth weeks: 4 series of 10 jumps, with overload of $60 \%$ of the body weight;

- Fifth and sixth weeks: 4 series of 10 jumps, with overload of $70 \%$ of the body weight;

- Seventh and eighth week: 4 series of 10 jumps, with $80 \%$ overhead of the body weight;

This protocol was chosen based on the similarity of number of sets, repetitions, rest period and strength training frequency with resistance training protocol applied in humans.

\section{Fish oil administration}

Animals from the EXFO group received supplementation of $2 \mathrm{~g} / \mathrm{kg} /$ day of fish oil as recommended by Simopoulos [26], containing omega-3 PUFA, $50 \mathrm{mg}$ EPA and $50 \mathrm{mg}$ DHA (Ativus Farmacêutica Ltda, Valinhos, São Paulo Brazil). Administration was performed after eight-week resistance exercise sessions using a stomach tube adapted to a five miligram syringe (gavage method).

\section{Muscle collection and histological analysis}

After 12, 24 and 48 hours from the last resistance exercise session, the animals were anesthetized with Hypnol ${ }^{\circledR}$ (pentobarbital sodium). The entire gastrocnemius muscle was removed with right lower limb posterior region incision and weighed. The gastrocnemius muscle was chosen due to a greater proportion of type II muscle fibers [27], recruited in activities with a high speed of contraction and great strength per motor unit. The samples were put on microscope slides and stained with hematoxylin and eosin for histological analysis under light microscopy.

\section{Microscopic analysis and photomicrography}

Histological sections were evaluated by an experienced professional, without prior knowledge of the experiment, using a Nikon ${ }^{\circledR}$ Eclipse E-200 microscope. In order to evaluate the degree of damage process, one slide per animal was analyzed. For qualitative analysis, each slide was analyzed in 20 fields with magnification from 40 to 100 times in different foci in areas identified as "hot spots". For quantitative analysis, the intensity of the neutrophilic infiltrate (inflammatory response) edema (fiber dissociation) and necrosis (sarcolemma destruction) were evaluated in the histological sections, and a system of parameters (scores) was established by Brasileiro et al. [28] and is described in Chart 1. Arithmetic means of values found in the 20 fields counted in each slide, corresponding to one animal in each group, were calculated for each parameter.

Chart 1. Microscopy parameters of muscle damage and damage intensity degree.

\begin{tabular}{|l|c|c|c|c|}
\hline \multirow{2}{*}{ Parameter } & \multicolumn{4}{|c|}{ Score } \\
\cline { 2 - 6 } & Grade 0 (absent) & Grade 1 (mild) & Grade 2 (moderate) & Grade 3 (intense) \\
\hline Edema & Absent & 1 gap per field (100x) & $2-4$ gap per field (100x) & $>5$ gaps per field (100x) \\
\hline Neutrophil infiltrate & Absent & $1-10$ neutrophils per field (400x) & $11-20$ neutrophils per field (400x) & $>20$ neutrophils per field (400x) \\
\hline Necrosis & Absent & 1 fiber per field (100x) & $2-3$ fibers per field (100x) & $>4$ fibers per field (100x) \\
\hline
\end{tabular}

From Brasileiro et al. [28]. 


\section{Statistical analysis}

Data were expressed as mean and standard deviation. The analysis was initially performed by the Kolmogorov-Smirnov normality test and after normality was checked, Variance Analysis (ANOVA) was performed, complemented by Tukey's multiple comparisons test. The null hypothesis significance level for rejection was 0.05 . For all tests, the program Graphpad Prism 5.0 (San Diego, California, USA) was used.

\section{RESULTS}

As for semi-quantitative analysis, we observed that the distance of muscle fibers presented higher scores in the groups corresponding to 24 and 48 hours post-resistance exercise. The animals that took fish oil had statistically more favorable dissociation scores of muscle fibers in comparison with the ones that were submitted to exercise and did not take fish oil (Figure 1A).

As for inflammatory infiltrate, the animals that received fish oil presented more representative scores for mild to moderate degree, while the animals that did not receive fish oil presented more scores that were moderate to intense, featuring numerous cells per field (Figure 1B).

The animals belonging to the groups that took fish oil presented at most one fiber with necrosis, while the animals that exercised and did not take fish oil had at least two fibers with necrosis per field (Figure 1C).

Qualitative analysis of muscle fibers demonstrated that the skeletal muscle cells of the group that did not take fish oil presented intense edema among the fibers and small neutrophil infiltration (Figure 2A). Necrosis, neutrophilic infiltration and edema were manifested by the gap of muscle cells due to interposition of interstitial fluid (Figure 2B). A large focus of necrosis characterized by muscle cells of hyaline staining without nucleus in their usual topography was identified (Figure 2C). In sections in which the exercised animals took omega-3 PUFA, moderate degree of intercellular edema and the focal and sparse presence of acute inflammation (neutrophils) were identified (Figure 2D). A moderate edema was observed among the fibers and moderate neutrophil infiltration (Figure 2E). Despite the area of necrosis characterized by hyalinized muscle tissue and mild edema, fibers with normal contours were observed (Figure 2F).
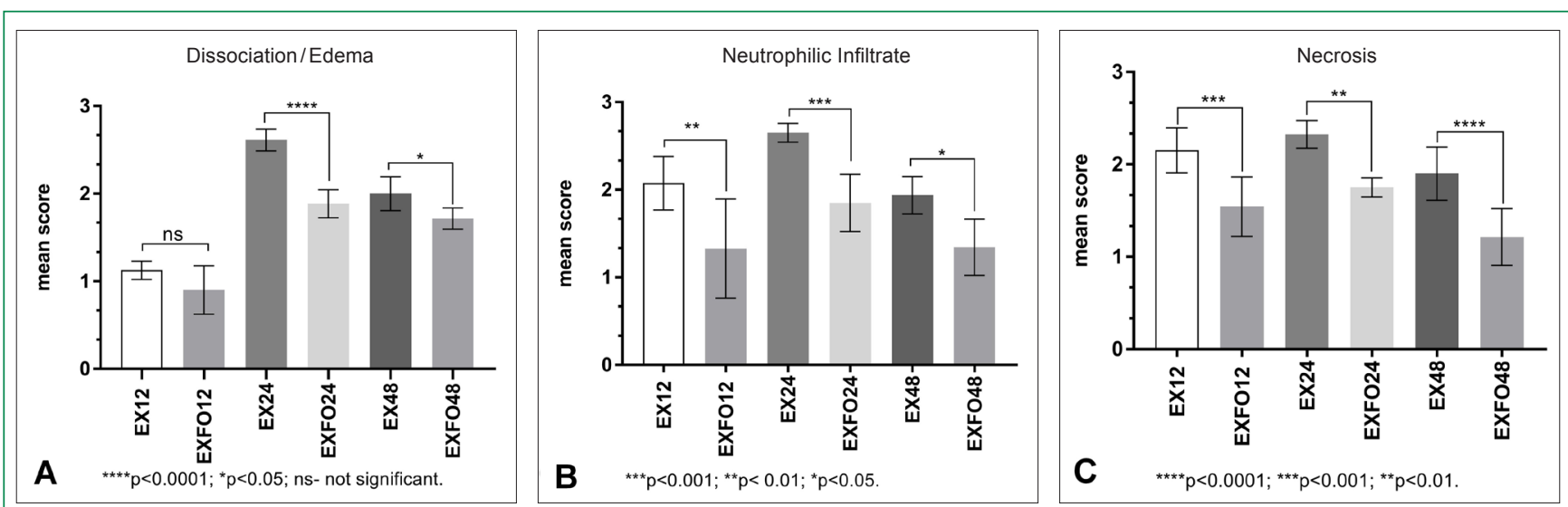

EX12: Group that did not take fish oil; muscle withdrawal procedure 12 hours after the last exercise session. EXFO 12: Group that ingested fish oil; muscle withdrawal procedure 12 hours after the last exercise session. EX24: Group that did not take fish oil; muscle withdrawal procedure 24 hours after the last exercise session. EXFO 24: Group that ingested fish oil; muscle withdrawal procedure 24 hours after the last exercise session. EX48: Group that did not take fish oil; muscle withdrawal procedure 48 hours after the last exercise session. EXFO 48:Group that ingested fish oil; muscle withdrawal procedure 48 hours after the last exercise session.

Figure 1. Mean and standard deviation of muscle fiber dissociation (A), muscle fiber neutrophilic infiltrate (B) and muscle fiber necrosis (C) analysis scores for subgroups of Wistar rats with or without fish oil intake, all of which were subjected to resistance exercise. 

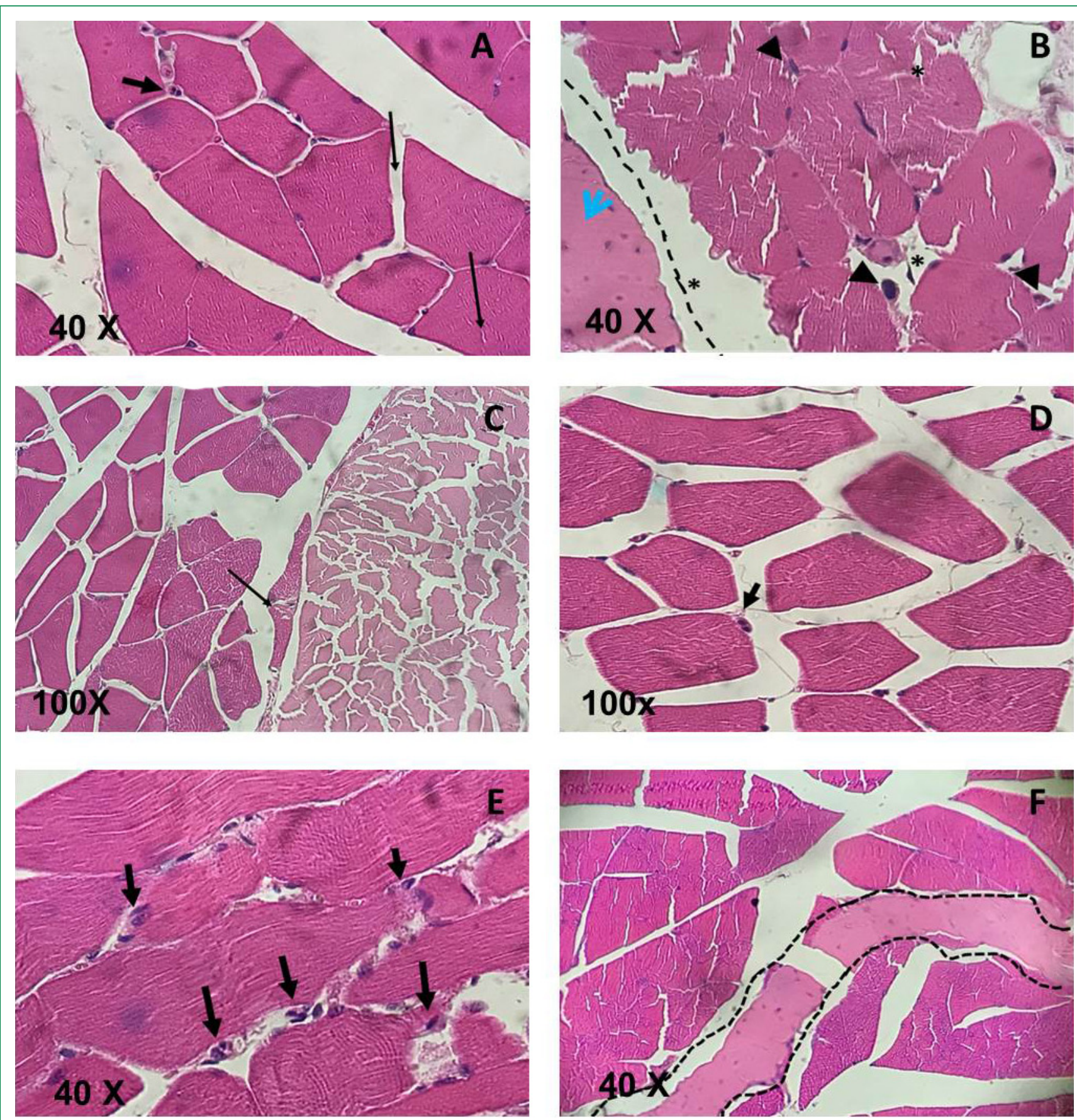

A: EX12 group (no fish oil, examination 12 hours after exercise): intense edema (long arrows) and slight neutrophilic infiltrate (short arrow).

B: EX24 group (no fish oil, examination 24 hours after exercise): necrosis (dashed line - blue arrow) neutrophilic inflammation (black pointers) and intercellular edema (asterisk). C: EX48 group (no fish oil, examination 24 hours after exercise): large focus of necrosis characterized by muscle cells of hyaline staining with the nucleus in topography.

D: EXFO12 group (fish oil, examination 12 hours after exercise): moderate degree of intercellular edema and focal and sparse presence of acute inflammation (neutrophils) (arrow). E: EXFO24 group (fish oil, examination 24 hours after exercise): moderate edema and moderate neutrophilic inflammation (black arrows).

F: EXFO48 group (fish oil, and examination 48 hours after exercise): necrosis area characterized by hyalinized muscle tissue and edema (observe the contrast with the shaded normal area of muscle).

Figure 2. Photomicrographs of the gastrocnemius muscle histological sections of Wistar rats with or without fish oil intake, all of which were subjected to resistance exercise. 


\section{DISCUSSION}

This study found fish oil effects on morphological aspects of muscle fibers after high-intensity exercise. The mechanisms of injury are still studied and are controversial. It has been commonly assumed that mechanical stress causes several cellular changes such as increase of the cytoplasmic calcium concentration, which causes proteolysis and lipolysis in the muscle cells' membrane, since it is able to activate specific enzymes sensitive to its high concentration. Furthermore, mechanical stress may affect the excitation-contraction process [29]. Intracellular accumulation of calcium favors phospholipase A2 activation and induces production of prostaglandins, leukotrienes and free radicals (powerful chemical mediators of inflammation), mainly from arachidonic acid in the membrane structure [30].

Different from our experimental exercise model, Garcia et al. [31] submitted rats for 28 days to continuous aerobic training with an overload of $5 \%$ of body weight and supplemented with fish oil. Histological analyzes of the soleus muscle of the animals supplemented with fish oil showed that the fibers had no increase in endomysial tissue, peripheral nuclei with reduced phagocytosis, and less pronounced polymorphism. Histological patterns of muscle damage were observed in the specimens from animals that trained without fish oil supplementation. In that study, the authors pointed out that the use of fish oil had a protective effect against muscular injuries [31]. In the same way, despite the use of different techniques, our study observed intense edema, neutrophilic inflammation and foci of necrosis in groups that performed resistance exercise and did not take fish oil. According to the classification of damage established for our study, the frequency of animals that presented moderate and intense edema was higher in groups that exercised without the supplementation with fish oil. Most of the animals belonging to the groups that received fish oil had no neutrophilic infiltrate. Some degree of necrosis was observed more frequently in animals that exercised without the use of fish oil.

It is important to notice that higher systemic omega-3 PUFA levels correlate with its increased concentration in the muscle cell membrane, increasing elasticity, flexibility and reduced risk of damage after intense exercise [32,33]. Possibly, the strategy of fish oil intake used in our experimental model contributed to the lower amplification of damages.

According to Tsuchiya et al. [34], omega-3 PUFA incorporation into the muscle cells membrane relieves tissue inflammation, thus suppressing the rupture of neuromuscular junction and the post-synaptic electrical transition. After exercise-induced muscle damage, a local inflammatory response is triggered, and accompanied by some edema. Neutrophils migrate to the damage site and the fight against the damaged tissue begins. Between 6 and 12 hours, monocytes accumulate in the site and a peak concentration occurs in about 48 hours after exercise. Monocytes are converted into macrophages, which synthesize large amounts of prostaglandin E2 [35].

Inflammation is a physiological response to tissue damage. It is primarily characterized by an increase in the cytokine expression, such as TNF- $\alpha$, interleukin (IL)-1 $\beta$ and IL-6 [36]. Cytokines can trigger release of acute phase proteins and inflammatory mediators, such as leukotriene and prostaglandin. In a recent study with male subjects, Jakeman et al. [37] have shown that acute ingestion of fish oil may inhibit elevation of serum cytokines and markers of muscle damage after jumping exercises. Muscle recovery after exercise influences training adaptations. Relatively recent studies corroborate our findings, demonstrating the considerable effect of omega-3 PUFA on muscle recovery and repair on muscle fiber damage $[34,38]$.

Mickleborough et al. [39] reported attenuation of muscle injury blood markers (troponin I, myoglobin, creatine kinase) and inflammation (TNF- $\alpha$ ) associated with the use of omega-3 PUFA-rich supplement after muscle injury induced by intense exercise. A study developed with wheelchair basketball athletes concluded that the use of fish oil supplementation rich in DHA prevented muscle injury, as well as changes in the profile of inflammatory mediators, neutrophil function and necrosis. Unlike this study, the subjects were supplemented daily for 30 days with $3 \mathrm{~g}$ of fish oil [40].

Brouard and Pascaud [41] studied inflammatory mediators in rats with diet composed of fish oil (rich in EPA and DHA), and reported a statistically significant decrease in inflammatory mediators. This can be explained because the anti-inflammatory effects of omega-3 PUFA are due to the decrease in the arachidonic acid content of the membranes resulting in the synthesis of eicosanoids derived from the diminished omega-6 PUFA [42-46].

Russ et al. [47] investigated the effect of eight weeks of fish oil supplementation on attenuation of contusion injuries in rats. The contusion model used by the authors produced significant muscle impairment, and the study showed that fish oil intake did not improve nor worsen the lesion. However, the authors observed an increase in myogenic factors and 
a decrease in mitofagia factors that may suggest fish oil as a potential strategy in post-injury recovery [47].

The slightest changes observed in the muscle fibers of fish-eating animals may be related to the fish oil anti-inflammatory properties, by reducing pro-inflammatory mediator synthesis, and preventing inflammatory response exacerbation to muscle damage process induced by physical stress due to resistance exercise. These findings can be explained by the fact that omega-3 PUFA rich compounds such as fish oil compete with arachidonic acid, reducing production of pro-inflammatory compounds (prostaglandin E2, thromboxane A2, prostaglandin I2, leukotriene 4) resulting from this acid, and favoring less active compound production (leukotriene 5, prostaglandin E3, thromboxane A3, prostaglandin I3) with antiinflammatory potential derived from omega-3 PUFA $[48,49]$.

The production of leukotriene 5 was demonstrated in macrophages of rats fed with fish oil [50] and human neutrophils supplemented with fish oil for several weeks [51-53]. Eicosanoids derived from omega-3 PUFA are much less biologically active than those produced from arachidonic acid are. Omega-3 derived leukotriene B5 have 10 to 100 times less neutrophil chemoattractant potential compared to leukotriene B4 $[54,55]$.

We lost four experimental animals belonging to the group that took the fish oil. As a limitation of the study we did not investigate animal deaths, but we can not relate them to any adverse effects of fish oil. Studies report few adverse effects with the use of omega-3 PUFA-rich supplements. Doses greater than $3 \mathrm{~g} /$ day in humans have been related to higher risks of hemorrhagic events due to a longer bleeding time $[11,56,57]$. Simopoulos [26] recommends that most athletes, especially at the leisure level, should include in their diet about 1-2 g/day of omega-3 PUFA.

We concluded that the physical exercise model applied in this study produced morphological changes in muscle cells and fish oil intake seems to be a useful resource for the muscle protection or recovery, since it attenuated the changes, demonstrated by smaller scores of edema, neutrophilic infiltrate and necrosis in muscle tissue.

\section{NOTES}

Funding

This study did not receive financial support from outside sources.

\section{Conflicts of interest disclosure}

The authors declare no competing interests relevant to the content of this study.

\section{Authors' contributions}

All the authors declare to have made substantial contributions to the conception, or design, or acquisition, or analysis, or interpretation of data; and drafting the work or revising it critically for important intellectual content; and to approve the version to be published.

Availability of data and responsibility for the results

All the authors declare to have had full access to the available data and they assume full responsibility for the integrity of these results.

\section{REFERENCES}

1. Aoi W, Naito Y, Yoshikawa T. Exercise and functional foods. Nutrition J [Internet]. 2006 [cited 2017 Mar 27]; 5:15. Available from: http://www.nutritionj.com/content/5/1/15

2. Tipton KD. Nutritional Support for Exercise-Induced Injuries. Sports Med. 2015;45 Suppl 1:S93-104. https://doi. org/10.1007/s40279-015-0398-4

3. Santos RV, Bassit RA, Caperuto EC, Costa Rosa LF. The effect of creatine supplementation upon inflammatory and muscle soreness markers after a 30km race. Life Sci. 2004;75(16):1917-24. https://doi.org/10.1016/j.1fs.2003.11.036

4. Volek JS, Ratamess NA, Rubin MR, Gómez AL, French DN, McGuigan MM, Scheett TP, Sharman MJ, Häkkinen K, Kraemer WJ. The effects of creatine supplementation on muscular performance and body composition responses to short-term resistance training overreaching. Eur J Appl Physiol. 2004;91(5-6):628-37. https://doi.org/10.1007/s00421003-1031-z

5. Cooke MB, Rybalka E, Williams AD, Cribb PJ, Hayes A. Creatine supplementation enhances muscle force recovery after eccentrically-induced muscle damage in healthy individuals. J Int Soc Sports Nutr. 2009;6:13. https://doi. org/10.1186/1550-2783-6-13

6. Deminice R, Rosa FT, Franco GS, Jordao AA, Freitas EC. Effects of creatine supplementation on oxidative stress and inflammatory markers after repeated-sprint exercise in humans. Nutrition. 2013;29(9):1127-32. https://doi.org/10.1016/ j.nut.2013.03.003 
7. Lieber RL, Fridén J. Muscle damage is not a function of muscle force but active muscle strain. J Appl Physiol (1985). 1993;74(2):520-6. https://doi.org/10.1152/jappl.1993.74.2.520

8. Clarkson PM, Hubal MJ. Exercise-induced muscle damage in humans. Am J Phys MedRehabil. 2002;81(11 Suppl): S52-69. https://doi.org/10.1097/00002060-200211001- 00007

9. Jouris KB, McDaniel JL, Weiss EP. The Effect of Omega-3 Fatty Acid Supplementation on the Inflammatory Response to eccentric strength exercise. J Sports Sci Med. 2011;10(3):432-8.

10. Gray P, Chappell A, Jenkinson AM, Thies F, Gray SR. Fish oil supplementation reduces markers of oxidative stress but not muscle soreness after eccentric exercise. Int J Sport Nutr Exerc Metab. 2014;24(2):206-14. https://doi.org/10.1123/ ijsnem.2013-0081

11. Ochi E, Tsuchiya Y. Eicosahexanoic Acid (EPA) and Docosahexanoic Acid (DHA) in Muscle Damage and Function. Nutrients. 2018;10(5):552. https://doi.org/10.3390/nu10050552

12. Calder PC. N-3 fatty acids, inflammation and immunity: new mechanisms to explain old actions. Proc Nutr Soc. 2013;72(3):326-36. https://doi.org/10.1017/S0029665113001031

13. Calder PC. Functional roles of fatty acids and their effects on human health. JPEN J Parenter Enteral Nutr. 2015;39 (1 Suppl):18S-32S. https://doi.org/10.1177/0148607115595980

14. Surette ME. The science behind dietary omega-3 fatty acids. CMAJ. 2008;178(2):177-80. https://doi.org/10.1503/ cmaj.071356

15. Molfino A, Gioia G, Rossi Fanelli F, Muscaritoli M. The role for dietary omega-3 fatty acids supplementation in older adults. Nutrients. 2014;6(10):4058-73. https://doi.org/10.3390/nu6104058

16. Baker EJ, Miles EA, Burdge GC, Yaqoob P, Calder P C. Metabolism and functional effects of plant-derived omega-3 fatty acids in humans. Prog Lipid Res. 2016;64:30-56. https://doi.org/10.1016/j.plipres.2016.07.002

17. Kremer JM. n-3 fatty acid supplements in rheumatoid arthritis. Am J Clin Nutr. 2000;71(1 Suppl):349S-51S. https://doi. org/10.1093/ajen/71.1.349s

18. DiLorenzo FM, Drager CJ, Rankin JW. Docosahexaenoic acid affects markers of inflammation and muscle damage after eccentric exercise. J Strength Cond Res. 2014;28(10):2768-74. https://doi.org/10.1519/JSC.0000000000000617

19. Houghton D, Onambele GL. Can a standard dose of eicosapentaenoic acid (EPA) supplementation reduce the symptoms of delayed onset of muscle soreness? J Int Soc Sports Nutr. 2012;9(1):2. https://doi.org/10.1186/1550-2783-9-2

20. Tartibian B, Maleki BH, Abbasi A. The effects of ingestion of omega-3 fatty acids on perceived pain and external symptoms of delayed onset muscle soreness inuntrained men. Clin J Sport Med. 2009;19(2):115-9. https://doi.org/10.1097/ JSM.0b013e31819b51b3

21. Haidamus LL. A suplementação com ácidos graxos poliinsaturados ômega-3 reduziu a concentração plasmática de eicosanóides pró-inflamatórios, da enzima lactato desidrogenase e de lesões musculares em ratos submetidos a sessões de natação [tese]. Campinas: Universidade Estadual de Campinas; 2007. 75 p. Available from: http://repositorio.unicamp. $\mathrm{br} / \mathrm{jspui} / \mathrm{handle} / \mathrm{REPOSIP} / 256329$

22. Fett CA. Composição corporal, ganho de força e resposta à exaustão, no treinamento hipertrófico, em presença da suplementação com ácidos graxos W-3 ou Triglicerídeo de cadeia média [dissertação]. Rio Claro: Universidade Estadual Paulista; 2001. 139 p.

23. Marqueti RC, Parizotto NA, Chriguer RS, Perez SE, Selistre-de-Araujo HS. Androgenic-anabolic steroids associated with mechanical loading inhibit matrix metallopeptidase activity and affect the remodeling of the achilles tendon in rats. Am J Sports Med. 2006;34(8):1274-80. https://doi.org/10.1177/0363546506286867

24. Renno AC, Silveira Gomes AR, Nascimento RB, Salvini T, Parizoto N. Effects of a progressive loading exercise program on the bone and skeletal muscle properties of female osteopenic rats. Exp Gerontol. 2007;42(6):517-22. https://doi. org/10.1016/j.exger.2006.11.014

25. Secchi KV, Morais CP, Cimatti PF, Tokars E, Gomes ARS. Efeito do alongamento e do exercício contra-resistido no músculo esquelético de rato. Rev Bras Fisioter. 2008;12(3):228-34. https://doi.org/10.1590/S1413-35552008000300011

26. Simopoulos AP. Omega-3 fatty acids and athletics. Curr Sports Med Rep. 2007;6(4):230-6.

27. Neves RVP, Souza MK, Passos CS, Bacurau RFP, Simões HG, Prestes J, Boim MA, Câmara NO, Franco Mdo C, Moraes MR. Resistance Training in Spontaneously Hypertensive Rats with Severe Hypertension. Cardiol. 2016;106(3):201-9. https://doi.org/10.1590/10.5935/abc.20160019

28. Brasileiro JL, Fagundes DJ, Miiji LON, Oshima CTF, Teruya R, Marks G, Inouye CM, Santos MA. Ischemia and reperfusion of the soleus muscle of rats with pentoxifylline. J Vasc Bras. 2007; 6(1):50-63. https://doi.org/10.1590/ S1677-54492007000100008

29. Proske U, Morgan DL. Muscle damage from eccentric exercise: mechanism, mechanical signs, adaptation and clinical applications. J Physiol. 2001;537(Pt 2):333-45. https://doi.org/10.1111/j.1469-7793.2001.00333.x

30. Armstrong RB. Initial events in exercise-induced muscular injury. Med Sci Sports Exerc. 1990;22(4):429-35.

31. Garcia BC, Camargo Filho JCS, Vanderlei LCM, Pastre CM, Camargo RCT, Souza TA, Haidamus LL, de Oliveira AC. Efeitos da dieta suplementada com ômega-3 no músculo sóleo de ratos submetidos à natação: análise histológica e morfométrica. Rev Bras Med Esporte. 2010;16(5):363-7. https://doi.org/10.1590/S1517-86922010000500009 
32. Krumbholz R, Krumbholz K, Krumbholz C, Schirra N, Lembke P, inventors. [Novel use of omega-3-fatty acid(s)]. DE patent EP 2222292 A2. 2010 Sept 1. German.

33. Poudyal H, Panchal SK, Diwan V, Brown L. Omega-3 fatty acids and metabolic syndrome: effects and emerging mechanisms of action. Prog Lipid Res. 2011;50(4):372-87. https://doi.org/10.1016/j.plipres.2011.06.003

34. Tsuchiya Y, Yanagimoto K, Nakazato K, Hayamizu K, Ochi E. Eicosapentaenoic and docosahexaenoic acids-rich fish oil supplementation attenuates strength loss and limited joint range of motion after eccentric contractions: a randomized, double-blind, placebo-controlled, parallel-group trial. Eur J Appl Physiol. 2016;116:1179-88. https://doi.org/10.1007/ s00421-016-3373-3

35. Smith LL. Acute inflammation: the underlying mechanism in delayed onset muscle soreness? Med Sci Sports Exerc. 1991;23(5):542-51. https://doi.org/10.1249/00005768-199105000-00006

36. Northoff H, Berg A. Immunologic mediators as parameters of the reaction to strenuous exercise. Int J Sports Med. $1991 ; 12$ Suppl 1:S9-15. https://doi.org/10.1055/s-2007-1024743

37. Jakeman J R, Lambrick DM, Wooley B, Babraj J A, Faulkner JA. Effect of an acute dose of omega-3 fish oil following exercise-induced muscle damage. Eur J Appl Physiol. 2017;117(3):575-82. https://doi.org/10.1007/s00421-017-3543-y

38. Corder KE, Newsham KR, McDaniel JL, Ezequiel UR, Weiss EP . Effects of Short-Term Docosahexaenoic Acid Supplementation on Markers of Inflammation after Eccentric Strength Exercise in Women. J Sports Sci Med. 2016;15(1):176-83.

39. Mickleborough TD, Sinex JA, Platt D., Chapman RF, Hirt M. The effects PCSO-524®, a patented marine oil lipid and omega-3 PUFA blend derived from the New Zealand green lipped mussel (Perna canaliculus), on indirect markers of muscle damage and inflammation after muscle damaging exercise in untrained men: a randomized, placebo controlled trial. J Int Soc Sports Nutr. 2015;12(1):10. https://doi.org/10.1186/s12970-015-0073-Z

40. Marques CG, Santos VC, Levada-Pires AC, Jacintho TM, Gorjão R, Pithon-Curim TC, Cury-Boaventura MF. Effects of DHA-rich fish oil supplementation on the lipid profile, markers of muscle damage, and neutrophil function in wheelchair basketball athletes before and after acute exercise. Appl Physiol Nutr Metab. 2015;40(6):596-604. https://doi.org/10.1139/ apnm-2014-0140

41. Brouard C, Pascaud M. Effects of moderate dietary supplementations with n-3 fatty acids on macrophage and lymphocyte phospholipids and macrophage eicosanoid synthesis in the rat. Biochim Biophys Acta. 1990;1047(1):19-28. https://doi. org/10.1016/0005-2760(90)90255-V

42. Browning LM. n-3 Polyunsaturated fatty acids, inflammation and obesity-related disease. Proc Nutr Soc. 2003;62(2): 447-53. https://doi.org/10.1079/PNS2003252

43. Giugliano D, Ceriello A, Esposito K. The effects of diet on inflammation: emphasis on the metabolic syndrome. J Am Coll Cardiol. 2006;48(4):677-85. https://doi.org/10.1016/j.jacc.2006.03.052

44. Lombardo YB, Chicco AG. Effects of dietary polyunsaturated n-3 fatty acids on dyslipidemia and insulin resistance in rodents and humans. A review. J Nutr Biochem. 2006;17(1):1-13. https://doi.org/10.1016/j.jnutbio.2005.08.002

45. Calder PC. Immunomodulation by omega-3 fatty acids. Prostaglandins Leukot Essent Fatty Acids. 2007;77(5-6):327-35. https://doi.org/10.1016/j.plefa.2007.10.015

46. Gopinath B, Buyken AE, Flood VM, Empson M, Rochtchina E, Mitchell P. Consumption of polyunsaturated fatty acids, fish, and nuts and risk of inflammatory disease mortality. Am J Clin Nutr. 2011;93(5):1073-9. https://doi.org/10.3945/ ajen.110.009977

47. Russ DW, Garvey SM, Densmore C, Hawks T, Herman S, Pardi K. Effect of acute muscle contusion injury, with and without dietary fish oil, on adult and aged male rats: contractile and biochemical responses. Exp Gerontol. 2018;111(1): 241-52. https://doi.org/10.1016/j.exger.2018.08.001

48. Molnar AM. Alterações mitocondriais e estresse oxidativo muscular induzidos por um treinamento físico: influência do exercício excêntrico e da suplementação com ácidos graxos ômega-3 [tese]. Campinas: Universidade Estadual de Campinas; 2005. 97 p.

49. Kelley DS. Modulation of human immune and inflammatory responses by dietary fatty acids. Nutrition. 2001;17 (7-8):669-73. https://doi.org/10.1016/S0899-9007(01)00576-7

50. Chapkin RS, Akoh CC, Miller CC. Influence of dietary n-3 fatty acids on macrophage glycerophospholipid molecular species and peptidoleukotriene synthesis. J Lipid Res. 1991;32(7):1205-13.

51. Lee TH, Hoover RL, Williams JD, Sperling RI, Ravalese J 3rd, Spur BW, et al. Effect of dietary enrichment with eicosapentaenoic and docosahexaenoic acids on in vitro neutrophil and monocyte leukotriene generation and neutrophil function. N Engl J Med. 1985;312(19):1217-24. https://doi.org/10.1056/NEJM198505093121903

52. Endres S, Ghorbani R, Kelley VE, Georgilis K, Lonnemann G, Van der Meer JW, Cannon JG, Rogers TS, Klempner MS, Weber PC, Schaefer EJ, Wolff SM, et al. The effect of dietary supplementation with n-3 polyunsaturated fatty acids on the synthesis of interleukin-1 and tumor necrosis factor by mononuclear cells. N Engl J Med. 1989;320(5):265-71. https://doi.org/10.1056/NEJM198902023200501

53. Sperling RI, Benincaso AI, Knoell CT, Larkin JK, Austen KF, Robinson DR. Dietary omega-3 polyunsaturated fatty acids inhibit phosphoinositide formation and chemotaxis in neutrophils. J Clin Invest. 1993;91(2):651-60. https://doi. org/10.1172/JCI116245 
54. Goldman DW, Pickett WC, Goetzl EJ. Human neutrophil chemotactic and degranulating activities of leukotriene B5 (LTB5) derived from eicosapentaenoic acid. Biochem Biophys Res Commun. 1983;117(1):282-8. https://doi.org/10.1016/0006291X(83)91572-3

55. Lee TH, Menica-Huerta JM, Shih C, Corey EJ, Lewis RA, Austen KF. Characterization and biologic properties of 5,12-dihydroxy derivatives of eicosapentaenoic acid, including leukotriene B5 and the double lipoxygenase product. J Biol Chem. 1984;259(4):2383-9.

56. U.S. Food and Drug Administration. 21 CFR Part 184 [Docket No. 1999P-5332]. Federal Register. 2001; 69:2313-7.

57. U. S. Food and Drug Administration. Letter Regarding Dietary Supplement Health Claim for Omega-3 Fatty Acids and Coro-Nary Heart Disease. [Docket No. 91 N-0103]. 2000. 